\title{
Evaluation of Embryotoxic Potential of Olaquindox and Vitamin A in Micromass Culture and in Rats
}

\author{
Hwan Goo Kang', Hyun Ok Ku', Sang Hee Jeong ${ }^{2}$, Joon Hyoung Cho' and Seong Wan Son' \\ ${ }^{1}$ National Veterinary Research and Quarantine Service, Anyang 430-757 \\ ${ }^{2}$ GLP Research Center, College of Natural Sciences, Hoseo University, Asan 336-795, Korea
}

(Received May 4, 2010; Revised May 16, 2010; Accepted May 31, 2010)

\begin{abstract}
Limb bud (LB) and central nerve system (CNS) cells were prepared from 12.5 day old pregnant female Crj:CD (SD) rats and treated with olaquindox and vitamin A. Cytotoxicity and inhibition on differentiation were measured in each cell. Three doses of olaquindox $(4,21$ and $100 \mathrm{mgkg})$, and 0.2 and $75 \mathrm{mg} / \mathrm{kg}$ of vitamin A were administered to pregnant rat for 11 days from $6^{\text {th }}$ to $16^{\text {th }}$ of pregnancy. $\mathrm{IC}_{50}$ values of olaquindox for proliferation and differentiation in CNS cell were 22.74 and $28.32 \mu \mathrm{g} / \mathrm{m} l$ and 79.34 and $23.29 \mu \mathrm{g} / \mathrm{m} l$ in LB cell and those values of vitamin A were 8.13 and $5.94 \mu \mathrm{g} / \mathrm{m} l$ in CNS cell and 0.81 and $0.05 \mu \mathrm{g} / \mathrm{ml}$ in LB cell, respectively. Mean body weights of pregnant rats were decreased at high dose of olaquindox $(110 \mathrm{mg} / \mathrm{kg})$ but relative ovary weight, number of corpus lutea, and number of implantation were not changed. Resorption and dead fetus were increased at high dose of olaquindox, and relative ovary weight, the number of corpus lutea and implantation, and sex ratio of male to female were not significantly changed in all dose of olaquindox. Mean fetal and placenta weights were significantly $(\mathrm{p}<0.01)$ decreased in rats of high group. Seven fetuses out of 103 showed external anomaly like bent tail, and 10 out of 114 fetuses showed visceral anomalies at high group. The ossification of sternebrae and metacarpals were significantly $(\mathrm{p}<0.01)$ increased by low and middle dose of olaquindox but it was significantly $(p<0.01)$ prohibited by high dose of olaquindox. In rats treated with vitamin A, the resorption and dead fetus were increased by high dose. Mean fetal weights were significantly $(p<0.01)$ increased by low dose but significantly $(\mathrm{p}<0.01)$ decreased by high dose. Thirty four fetuses out of 52 showed external anomaly; bent tail (1), cranioarchschisis (14), exencephaly (14), dome shaped head (22), anophthalmia (15), brcahynathia (10) and others (19). Forty five fetuses out of 52 showed soft tissue anomaly; cleft palate (42/ 52 ) and anophthalmia (22/52) by high dose of vitamin A. Sixty one fetuses out of $61(85.2 \%)$ showed skull anomaly; defect of frontal, partial and occipital bone (21/61), defect of palatine bone (52/61) and others $(50 / 61)$. In summary, we support that vitamin A is strong teratogen based on our micromass and in vivo data, and olaquindox has a weak teratogenic potential in LB cell but not in CNS cell. We provide the in vivo evidence that a high dose of olaquindox could have weak embryotoxic potential in rats.
\end{abstract}

Key words: Olaquidox, Vitamin A, Teratogenicity, Rat, Micromass

\section{INTRODUCTION}

Olaquindox, a synthetic antimicrobial compound, was used as growth promoting feed additives in animal industry (Bronsch et al., 1976; Schneider et al., 1976). Although it has been abandoned in most developed countries but it still was used in some developing countries for growth promotion (Chen et al., 2009). Olaquindox, N-(2-hydroxyethyl)-3-

Correspondence to: Hwan Goo Kang, Toxicology and Chemistry Division, National Veterinary Research and Quarantine Service, 480, Anyang 6-dong, Anyang city 430-757, Korea

E-mail: kanghg67@korea.kr
methyl-2-quinoxalinecarboxamide-1,4-di-N-oxide, is one of the quinoxaline-dioxides used widely as an antimicrobial growth promoter in pig production. Its toxicities were reported to be closely related to the formation of $\mathrm{N}$-oxide reductive metabolites (Liu et al., 2010).

Olaquindox increased the DNA fragmentation in Vero cells, but DNA damage was decreased after incubation with $\mathrm{S}_{9}$ mix (Chen et al., 2009). Olaquindox or some of its metabolite showed mutagenic activity (Beutin et al., 1981; Ding et al., 2006; Hao et al., 2006). Olaquindox increased genotoxic effects in HepG2 cells through the ROS-induced oxidative DNA damage (Chen et al., 2009). It brought out photo allergic contact dermatitis (Belhadjali et al., 2002). 
Owing to its genotoxicity no threshold can be established for the safe usage of olaquindox, and the Commission of the European Community forbad the usage of olaquindox as an animal growth promoter in 1998 (Commission of the European Communities, 1998). However, it is still broadly used in some developing countries for promoting animal growth and its toxic effects need careful evaluation.

Although traditional toxicology tests have relied on whole animal test to provide information on the evaluation of toxicity; these tests are quite expensive and time consuming. Micromass using LB and CNS cell has been used as an effective tool to screen teratogenicity (Kistler, 1987; Kistler and Howard, 1990; Flint, 1993) and was demonstrated as a potential short term screen for teratogenic potency (Flint and Orton, 1984; Flint, 1986). Lim bud mesenchymal cells when they grown in high-density can proliferate and differentiate into a number of cell types such as cartilage and muscle. So, this cell was used to study of in vitro chondrogenesis as shown by the occurrence of cartilaginous foci made with chondrocytes to secrete proteoglycana and collagen (Zanetti and Solursh, 1984; Paulsen and Solursh, 1988). Using Alcian blue, a stain specific for cartilage proteoglycans, the degree of chondrogenesis can be visualized in the micromass cultures as well as quantified by extraction of the stain and spectrophotometric determination of its absorbance. Several studies have shown a fairly good correlation between inhibition of chondrogenesis in vitro and teratogenic activity in vivo (Flint and Orton, 1984; Guntakatta et al., 1984; Wise et al., 1990; Aulthouse and Hitt, 1994).

In present study, we evaluated the teratogenicity of olaquindox and vitamin A using miscromass culture of limb bud and midbrain cell from 12.5 days of fetus and examined teratogenic and embryonic toxicity potential of those compounds in rats to compare with those result in micromass study.

\section{Materials and methods}

Animals. Eight week old female and male Crj:CD (SD) rats were provided by National Veterinary Research and Quarantine Service (Anyang, Republic of Korea). Rats were provided with tap water and a commercial diet ad libitum. The animal room was maintained at a temperature of $24 \pm 2^{\circ} \mathrm{C}$, a relative humidity of $50 \pm 20 \%$, and a $12 \mathrm{~h}$ light/ dark cycle. All animals were cared for according to the Code of Laboratory Animal Welfare and Ethics of the NVRQS. Experimental design was approved by the NVRQS Animal Welfare Committee.

Preparation and culture of limb bud and CNS cells. Female rats were mated overnight and the appearance of sperms in vaginal smear was regarded as 0 day of gestation. On the day of 12 uteri were removed and embryo were separated for the micromass culture. Forelimb bud and mid- brain were separated and LB and CNS cell were prepared by Flint and Orton (1984) method with modification by Kidney and Faustman (1995). Briefly, after trypsinization of midbrain and forelimb bud, medium was added to produce $5 \times 10^{6}$ cells $/ \mathrm{m} l$ for $\mathrm{CNS}$ cell and $2 \times 10^{7}$ cells $/ \mathrm{m} l$ for $\mathrm{LB}$ cell.

Chemical exposure in micromass. Stock solution of vitamin A (Sigma, Republic of Korea) and olaquindox (Dahee, Republic of Korea) were dissolved in dimethylsulfoxide. Dilutions were prepared by adding medium not exceeding $1 \%(\mathrm{v} / \mathrm{v})$. Plated cells were cultured for $2 \mathrm{~h}$ at $37^{\circ} \mathrm{C}, 5 \% \mathrm{CO}_{2}$ incubator for the attachment of cells, after which medium containing test compound was replaced. Exposure concentrations were $6,14,32,73,166 \mu \mathrm{g} / \mathrm{m} l$ in both LB and CNS for olaquindox. Concentration of vitamin A in CNS cell were 2.3, 5, 10.8, 23.3 and $50.0 \mu \mathrm{g} / \mathrm{m} l$ for cytotoxicity and differentiation, and $0.16,0.38,0.89$, 2.12 and $5.0 \mu \mathrm{g} / \mathrm{m} l$ for cytotoxicity and $0.003,0.011,0.144$ and $0.50 \mu \mathrm{g} / \mathrm{m} l$ for inhibition of differentiation in LB cells.

Determination of cytotoxicity and inhibition on differentiation. Assessment of cytotoxicity and inhibition of differentiation was followed by the method of Kidney and Faustman (Kidney and Faustman, 1995) with some modification. For the assessment of cytotoxicity, $8 \mu l$ drops of CNS or LB cell suspension were plated in the well of collagen coated, warmed 96-well microplate. Medium was aspirated and cell was fixed in $4.5 \%$ glutaraldehyde for 20 min after 5 day culture. Cells were washed two times with PBS, and $200 \mu l$ of freshly prepared neutral red in PBS $(0.05 \% \mathrm{w} / \mathrm{v})$ was added to each well. After $1 \mathrm{~h}$, cells were rinsed with PBS twice, and $200 \mu l$ of $0.5 \%$ (v/v) acetic acid in ethanol was added to solve the dye. Absorbance was determined at $540 \mathrm{~nm}$ on microplate reader.

For the assessment of inhibition on differentiation on LB and CNS cells, $20 \mu l$ drops of CNS or LB cell suspension were plated in the well of primaria coated, warmed 6-well microplate. The differentiation of CNS cells was quantified by hematoxylin staining and by Alcian blue staining of proteoglycans for LB cells. Briefly, LB cells were fixed with $10 \%(\mathrm{v} / \mathrm{v})$ formaldehyde and $0.5 \%(\mathrm{w} / \mathrm{v})$ cetylpyridinium chloride solution for $20 \mathrm{~min}$. After washing with tap water, each well was treated with $3 \%$ acetic acid in $1 \mathrm{~N} \mathrm{HCl}$ for $1 \mathrm{~h}$ and then stained overnight with $1 \%(\mathrm{w} / \mathrm{v})$ Alcian blue. Each well was washed with $3 \%$ acetic acid in $1 \mathrm{~N} \mathrm{HCl}$. Small foci of cells which differentiated within each micromass island were counted. CNS cells were stained with Delafield's hematoxylin for $3 \mathrm{~min}$ and immersed in tap water $20 \mathrm{~min}$ to develop the color.

Embryotoxicity of olaquindox and vitamin $A$ in rats. Vitamin A was dissolved in corn oil and olaquindox was dissolved in $2 \%$ CMC. Pregnant rats were exposed to $4 \mathrm{mg} /$ 
$\mathrm{kg}$ (low group), $21 \mathrm{mg} / \mathrm{kg}$ (middle group) and $110 \mathrm{mg} / \mathrm{kg}$ bw (high group) of olaquindox and $0.2 \mathrm{mg}$ and $75 \mathrm{mg} / \mathrm{kg}$ bw of vitamin A, respectively, for 11 days from $6^{\text {th }}$ to $16^{\text {th }}$ of pregnancy. Rats were scarified 1 day before delivery and resorption, fetal weight and other indexes were observed to determine developmental toxicity. Gross external and internal malformations were examined first. Then, skeletal malformation were observed using a clearing technique by Staple and Schnell (1964) consisting of maceration in 1.0\% $\mathrm{KOH}$ and staining with Alizarin red S. To observe the malformation of head, heads were soaked into Bouin's fixative for 10 day.

Statistical analysis. $\mathrm{IC}_{50}$ values and $95 \%$ confidence limit were calculated with Litchfield and Wilcoxon II method using Pharm/PCS (ver 4.1, USA). Data were ana- lyzed by break down \& one-way ANOVA, followed by Duncan test as post-hoc comparison using Statistica (Ver. 5.5 , USA).

\section{RESULTS}

Effect of olaquindox and vitamin $A$ on the proliferation and differentiation in the limb bud and midbrain cells. Olaquindox and vitamin A inhibited dose-dependently the proliferation and differentiation of $\mathrm{LB}$ and CNS cell, respectively (Fig. 1, 2). $\mathrm{IC}_{50}$ values of olaquindox for the proliferation and differentiation in CNS cell were 22.74 and $28.32 \mu \mathrm{g} / \mathrm{ml}$, and 79.34 and $23.29 \mu \mathrm{g} / \mathrm{ml}$ in LB cell, respectively (Table 1). Regarding vitamin $\mathrm{A}, \mathrm{IC}_{50}$ values of proliferation and differentiation in CNS cell were 8.13 and $5.94 \mu \mathrm{g} / \mathrm{ml}$, and 0.81 and $0.05 \mu \mathrm{g} / \mathrm{ml}$ in LB cell, respec-
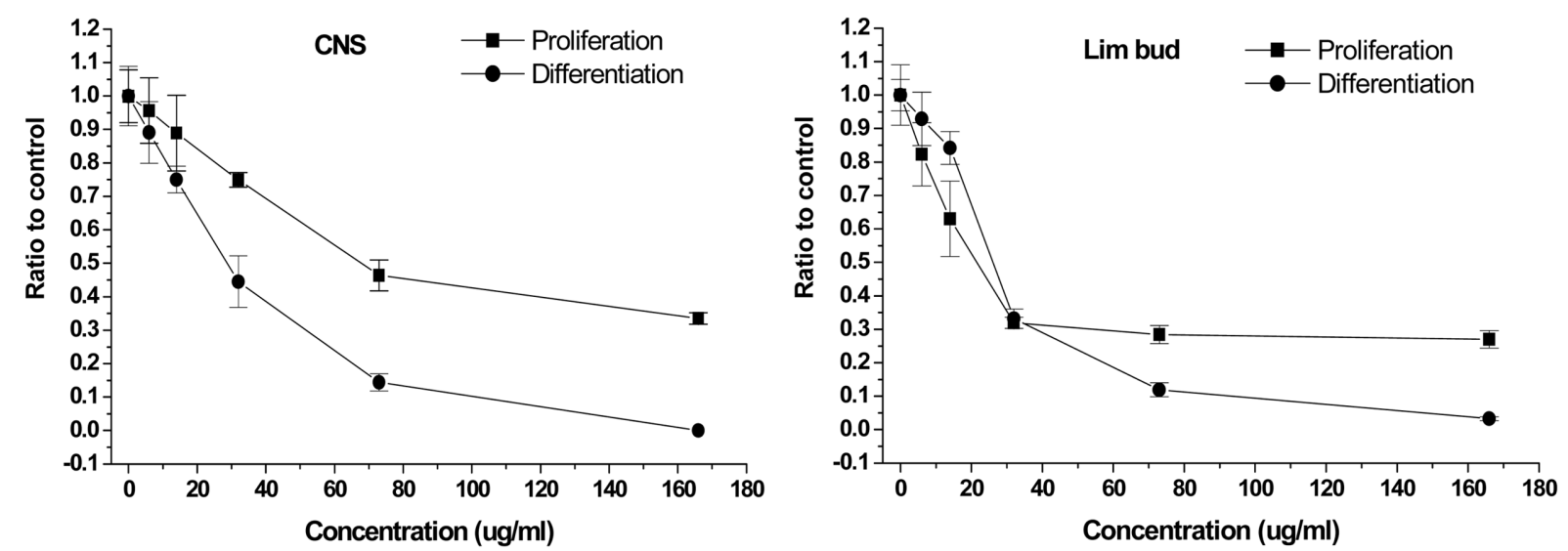

Fig. 1. Dose-response of olaquindox to micromass culture of CNS and LB cells from 12.5 day old rat embryo. Cell proliferation is measured as specrtophotometric estimation of neutral red uptake at $560 \mathrm{~nm}$ and differentiation as the number of foci per island which stained with hematoxylin for CNS and Alcian blue for LB cells after 5 days of culture. All points represent mean of 4 6 experiments with standard deviation. Where no bars are observed, they fall within the plot symbol.
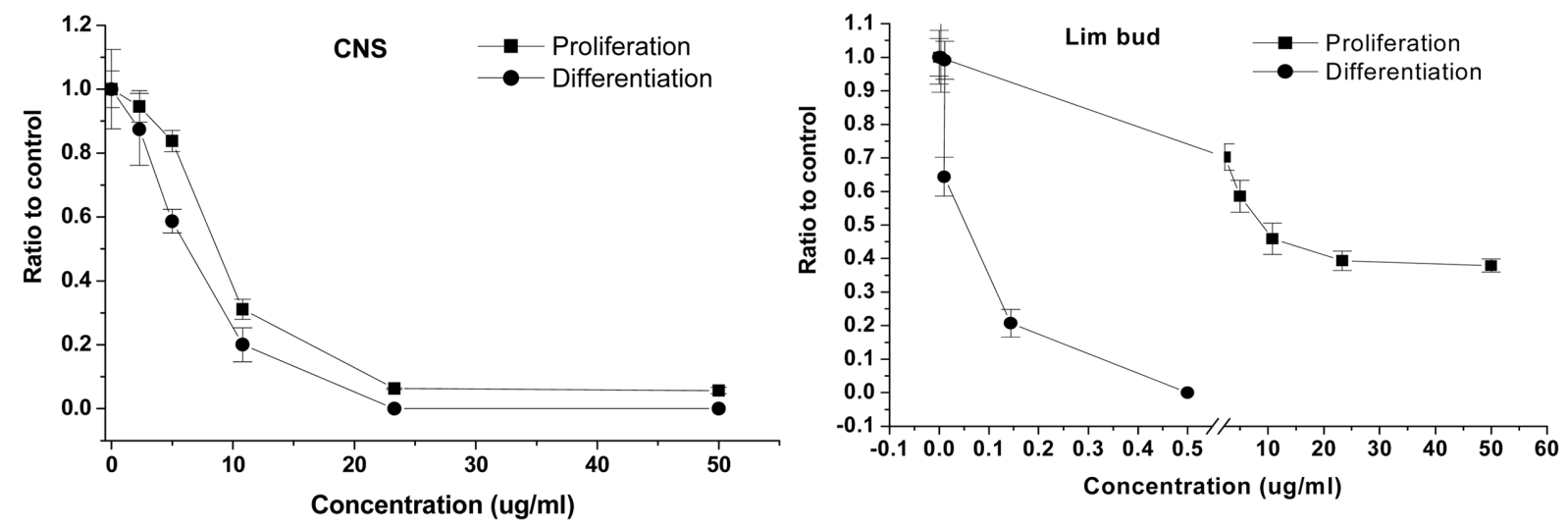

Fig. 2. Dose-response of vitamin A acetate to micromass culture of CNS and LB cells from 12.5 day old rat embryo. Cell proliferation is measured as specrtophotometric estimation of neutral red uptake at $560 \mathrm{~nm}$ and differentiation as the number of foci per island which stained with hematoxylin for CNS and Alcian blue for LB cells after 5 days of culture. All points represent mean of 4 6 experiments with standard deviation. Where no bars are observed, they fall within the plot symbol. 
Table 1. Inhibitory effects of olaquindox on proliferation and differentiation of CNS and LB cells

\begin{tabular}{llcc}
\hline \hline Cells $^{\mathrm{a}}$ & & $\mathrm{IC}_{50}(\mu \mathrm{g} / \mathrm{m} l)$ & 95\% Confidence limits \\
\hline \multirow{2}{*}{ CNS } & Proliferation & 22.74 & $18.31 \sim 28.24$ \\
& Differentiation & 28.32 & $23.62 \sim 33.95$ \\
\hline \multirow{2}{*}{ LB } & Proliferation & 79.34 & $63.16 \sim 99.67$ \\
& Differentiation & 23.29 & $19.28 \sim 28.13$ \\
\hline
\end{tabular}

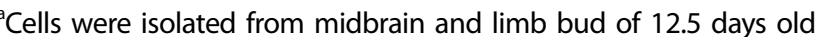
rat embryo.

Table 2. Inhibitory effects of vitamin A acetate on proliferation and differentiation of CNS and LB cells

\begin{tabular}{llcc}
\hline \hline Cell type $^{\mathrm{a}}$ & & ${ }^{\mathrm{b}} \mathrm{IC}_{50}(\mu \mathrm{g} / \mathrm{m} l)$ & $95 \%$ Confidence limits \\
\hline \multirow{2}{*}{$\mathrm{CNS}$} & Proliferation & 8.13 & $7.10 \sim 9.31$ \\
& Differentiation & 5.94 & $5.10 \sim 6.93$ \\
\hline \multirow{2}{*}{ LB } & Proliferation & 0.81 & $0.51 \sim 1.27$ \\
& Differentiation & 0.05 & $0.04 \sim 0.07$ \\
\hline
\end{tabular}

${ }^{a}$ Cells were isolated from midbrain and limb bud of 12.5 day old rat embryo.

tively (Table 2).

Effect of olaquindox on embryonic development in rats. In rats given with olaquidox, mean body weight of mother rats was decreased and the rate of resorption and percentage of dead fetus was increased only at high group, whereas relative ovary weight, the number of corpus lutea and implantation, and sex ratio of male to female were not significantly changed by all dose of olaquindox (Table 3 ). Mean fetal weights were significantly $(p<0.05)$ increased in female and male rats of middle group but significantly $(p<0.01)$ decreased in rats of high group. Mean placenta weights were decreased only in rats of high group (Table 4). Seven fetuses out of 103 showed external anomaly like bent tail and it was increased compared to that of vehicle control (2/114; number of anomaly to examined fetuses). Regarding visceral anomalies, they were $6 / 114$ in control group and 10/103 in high group. Two fetuses out of 110 showed dilation of lateral ventricle at high group (Table 5). Skeletal anomaly was not observed at all group. The ossification of sternebrae and metacarpals were significantly $(p<0.01)$ increased by low and middle dose of olaquindox but it was significantly $(\mathrm{p}<0.01)$ prohibited at high group (Table 6$)$.

Effect of vitamin A on embryonic development in rats. In rats treated with vitamin $A$, mean body weight of mother was significantly $(p<0.01)$ decreased only at high group. The percentage of resorption and dead fetus were increased at high dose of vitamin A but sex ratio and number of implantation were not changed by the treatment of vitamin

Table 3. Effect of olaquindox and vitamin A on rat embryonic development

\begin{tabular}{|c|c|c|c|c|c|c|c|}
\hline \multirow{3}{*}{ Indices } & & \multicolumn{6}{|c|}{ Dose (mg/kg) } \\
\hline & & \multirow{2}{*}{0} & \multirow{2}{*}{4} & \multirow{2}{*}{21} & \multirow{2}{*}{110} & \multicolumn{2}{|c|}{ Vitamin A } \\
\hline & & & & & & 0.2 & 75 \\
\hline No. of dams & & 20 & 20 & 20 & 20 & 19 & 17 \\
\hline Mean B.W. of maternal rats $(\mathrm{g})$ & & $\begin{array}{c}370.83 \pm \\
30.24\end{array}$ & $\begin{array}{l}380.75 \pm \\
20.77\end{array}$ & $\begin{array}{c}369.28 \pm \\
26.88\end{array}$ & $\begin{array}{c}333.12 \pm \\
21.82\end{array}$ & $\begin{array}{l}352.67 \pm \\
21.06\end{array}$ & $\begin{array}{c}260.95 * * \pm \\
52.01\end{array}$ \\
\hline \multirow[t]{2}{*}{$\begin{array}{l}\text { Relative ovary weight of } \\
\text { maternal rat }(\mathrm{g})\end{array}$} & Left & $\begin{array}{c}0.018 \pm \\
0.005\end{array}$ & $\begin{array}{c}0.019 \pm \\
0.006\end{array}$ & $\begin{array}{c}0.018 \pm \\
0.003\end{array}$ & $\begin{array}{c}0.017 \pm \\
0.004\end{array}$ & $\begin{array}{c}0.018 \pm \\
0.004\end{array}$ & $\begin{array}{c}0.021 \pm \\
0.006\end{array}$ \\
\hline & Right & $\begin{array}{c}0.020 \pm \\
0.000\end{array}$ & $\begin{array}{c}0.020 \pm \\
0.010\end{array}$ & $\begin{array}{c}0.020 \pm \\
0.010\end{array}$ & $\begin{array}{c}0.020 \pm \\
0.010\end{array}$ & $\begin{array}{c}0.017 \pm \\
0.006\end{array}$ & $\begin{array}{c}0.021 \pm \\
0.006\end{array}$ \\
\hline No. of copora lutea & & $15.0 \pm 2.4$ & $15.0 \pm 1.9$ & $14.0 \pm 1.4$ & $15.0 \pm 2.3$ & $14.0 \pm 2.0$ & $15.0 \pm 2.0$ \\
\hline No. of implanta- tions & & $13.0 \pm 3.1$ & $15.0 \pm 1.7$ & $13.0 \pm 3$ & $14.0 \pm 2.6$ & $13.0 \pm 2.1$ & $14.0 \pm 3.9$ \\
\hline Implantation $\%{ }^{\mathrm{a}}$ & & 95.9 & 95.7 & 94.3 & 92.9 & 96.0 & 99.0 \\
\hline No. of resorptions & & $1.1 \pm 1.3$ & $0.9 \pm 0.9$ & $0.9 \pm 0.9$ & $1.7 \pm 2.0$ & $1.0 \pm 1.3$ & $7.7 \pm 6.2$ \\
\hline Resorption $\% \mathrm{~b}$ & & 8.2 & 5.9 & 6.3 & 12.3 & 6.8 & 51.0 \\
\hline No. of dead fetus & & $0.1 \pm 0.2$ & $0.0 \pm 0.0$ & $0.0 \pm 0.0$ & $0.3 \pm 0.7$ & $0.1 \pm 0.3$ & $0.4 \pm 0.8$ \\
\hline Dead fetuses $\%{ }^{\mathrm{c}}$ & & 0.4 & 0.0 & 0.0 & 2.1 & 0.7 & 3.1 \\
\hline No. of live fetuses & & $12.3 \pm 3.0$ & $13.8 \pm 1.6$ & $12.3 \pm 2.9$ & $12.0 \pm 3.1$ & $12.2 \pm 2.2$ & $6.5 \pm 5.0$ \\
\hline Live fetuses $\%^{\mathrm{d}}$ & & 93.8 & 94.1 & 93.8 & 85.7 & 92.0 & 49.0 \\
\hline \multirow[t]{2}{*}{ No. of sex } & Male & $6.1 \pm 1.9$ & $7.0 \pm 2.4$ & $5.6 \pm 2.1$ & $5.5 \pm 2.1$ & $6.5 \pm 2.0$ & $3.8 \pm 2.8$ \\
\hline & Female & $5.2 \pm 1.9$ & $6.8 \pm 1.8$ & $6.7 \pm 2.5$ & $6.5 \pm 2.3$ & $5.7 \pm 2.7$ & $3.3 \pm 2.7$ \\
\hline Sex ratio (male/female) & & 1.1 & 1.2 & 0.9 & 1.0 & 1.6 & 1.3 \\
\hline
\end{tabular}

a: values are percent of No. of implantations per No. of copora lutea.

${ }^{b}$ : values are percent of No. of resorptions per No. of implantations.

c: values are percent of No. of dead fetuses per No. of implantations.

${ }^{d}$ : values are percent of No. of live fetuses per No. of implantations. 
Table 4. Effect of olaquindox and vitamin A on fetal and placental weight

\begin{tabular}{llcccccc}
\hline \hline \multirow{2}{*}{ Indices } & \multicolumn{7}{c}{ Dose $(\mathrm{mg} / \mathrm{kg})$} \\
\cline { 2 - 8 } & \multicolumn{2}{c}{ Vehicle } & \multicolumn{3}{c}{ Olaquindox } & \multicolumn{1}{c}{ Vitamin A } \\
\cline { 3 - 9 } & & & 4 & 21 & 110 & 0.2 & 75 \\
\hline No. of dams & & 20 & 19 & 20 & 20 & 19 & 18 \\
No. of fetuses observed & & 245 & 263 & 245 & 240 & 232 & 110 \\
Mean fetal weight (g) & male & $3.68 \pm 0.29$ & $3.76 \pm 0.39$ & $3.86 \pm 0.33^{*}$ & $3.05 \pm 0.33^{* *}$ & $4.01 \pm 0.33^{* *}$ & $2.74 \pm 0.66^{* *}$ \\
& female & $3.49 \pm 0.31$ & $3.59 \pm 0.36$ & $3.65 \pm 0.25^{*}$ & $2.86 \pm 0.37^{* *}$ & $3.82 \pm 0.26^{* *}$ & $2.60 \pm 0.57^{* *}$ \\
Mean placenta weight (g) & male & $0.54 \pm 0.06$ & $0.54 \pm 0.04$ & $0.54 \pm 0.05$ & $0.40 \pm 0.08^{* *}$ & $0.54 \pm 0.06$ & $0.54 \pm 0.15$ \\
& female & $0.52 \pm 0.04$ & $0.51 \pm 0.04$ & $0.51 \pm 0.05$ & $0.38 \pm 0.08^{* *}$ & $0.55 \pm 0.07$ & $0.54 \pm 0.11$ \\
\hline
\end{tabular}

Values are represented as mean \pm SD for No. of fetuses observed.

***, significantly different from control at $p<0.05$ and $p<0.01$, respectively.

Table 5. Effect of olaquindox and vitamin A on external, visceral and soft tissue development in fetal rats

(No. of fetuses)

\begin{tabular}{|c|c|c|c|c|c|c|}
\hline \multirow{3}{*}{ Indices } & \multicolumn{6}{|c|}{ Dose (mg/kg) } \\
\hline & \multirow{2}{*}{ Vehicle } & \multicolumn{3}{|c|}{ Olaquindox } & \multicolumn{2}{|c|}{ Vitamin A } \\
\hline & & 4 & 21 & 110 & 0.2 & 75 \\
\hline No. of fetuses observed & 114 & 120 & 114 & 103 & 103 & 52 \\
\hline External anomaly & 2 & 1 & ND & 7 & ND & 34 \\
\hline Bent tail & 1 & 1 & ND & 3 & ND & 1 \\
\hline Craniorachschisis & ND & ND & ND & ND & ND & 14 \\
\hline Exencephaly & ND & ND & ND & ND & ND & 14 \\
\hline Dome shaped head & ND & ND & ND & ND & ND & 22 \\
\hline Anophthalmia & ND & ND & ND & ND & ND & 15 \\
\hline Brachygnathia & ND & ND & ND & ND & ND & 10 \\
\hline Others & 1 & ND & ND & 4 & ND & 19 \\
\hline External anomaly $\%{ }^{\mathrm{a}}$ & 1.8 & 0.8 & 0 & 6.8 & 0 & 55.7 \\
\hline Visceral anomaly & 6 & 7 & 4 & 10 & 8 & 7 \\
\hline Dilatation of renal pelvis & 3 & 4 & 2 & 6 & 4 & 4 \\
\hline Renal displacement & 2 & 3 & 1 & 3 & 4 & 0 \\
\hline Dilatation of ureter & 1 & ND & 1 & 2 & ND & 6 \\
\hline Others & ND & ND & ND & 1 & ND & 2 \\
\hline Visceral anomaly rate $\%$ & 5.3 & 5.8 & 3.5 & 9.7 & 7.8 & 13.5 \\
\hline Soft tissue anomaly & ND & 1 & ND & 2 & ND & 45 \\
\hline Cleft palate & ND & ND & ND & ND & ND & 42 \\
\hline Anophthalmia & ND & ND & ND & ND & ND & 22 \\
\hline Dilatation of lateral ventricle & ND & 1 & ND & 2 & ND & ND \\
\hline Others & ND & ND & ND & ND & ND & ND \\
\hline Soft tissue anomaly $\%$ & 0 & 0.8 & 0 & 1.9 & 0 & 86.5 \\
\hline
\end{tabular}

${ }^{a}$, Values are percentage of No. of fetuses showing anomaly per No. of fetuses observed.

$\mathrm{ND}$, anomaly not detected.

A (Table 3). Mean fetal weights were significantly $(\mathrm{p}<0.01)$ increased by low dose but significantly $(p<0.01)$ decreased in rats treated with high dose of vitamin A. The placenta weight was not changed by the treatment of vitamin $\mathrm{A}$ (Table 4). In rats treated with vitamin A, 34 fetuses out of 52 showed external anomaly which were bent tail (1), cranioarchschisis (14), exencephaly (14), dome shaped head (22), anophthalmia (15), brcahynathia (10) and others (19). Visceral anomaly such as dilatation of ureter was increased by high dose of vitamin A, which were 6 out of 52 at high group but 1 out of 114 fetuses in vehicle group. Forty five fetuses out of 52 showed soft tissue anomaly which were cleft palate (42/52) and anophthalmia (22/52) by high dose of vitamin A (Table 5). Sixty one fetuses out of $61(85.2 \%)$ showed skull anomaly which were defect of frontal, partial and occipital bone (21/61), defect of palatine bone (52/61) and others (50/61). dilation of lateral ventricle at high group (Table 5). The ossification of sternebrae and metacarpals were significantly $(p<0.01)$ increased by low dose but it was significantly $(\mathrm{p}<0.01)$ prohibited by high dose of vita- 
Table 6. Influence of olaquindox and vitamin A on skeletal development of fetal rats

(No. of fetuses)

\begin{tabular}{|c|c|c|c|c|c|c|}
\hline \multirow{3}{*}{ Indices } & \multicolumn{6}{|c|}{ Dose $(\mathrm{mg} / \mathrm{kg})$} \\
\hline & \multirow{2}{*}{ Vehicle } & \multicolumn{3}{|c|}{ Olaquindox } & \multicolumn{2}{|c|}{ Vitamin A } \\
\hline & & 4 & 21 & 110 & 0.2 & 75 \\
\hline No. of observed fetus & 131 & 149 & 131 & 120 & 117 & 61 \\
\hline Skull anomaly & ND & ND & ND & ND & ND & 52 \\
\hline Defect of frontal, parietal, occipital bone & ND & ND & ND & ND & ND & 21 \\
\hline Defect of palatine bone & ND & ND & ND & ND & ND & 52 \\
\hline Others & ND & ND & ND & ND & ND & 50 \\
\hline Anomaly \% & 0 & 0 & 0 & 0 & 0 & 85.2 \\
\hline Vertebrae anomaly & ND & ND & ND & ND & ND & 7 \\
\hline Sternebrae & $5.3 \pm 0.8^{\mathrm{a}}$ & $5.5 \pm 0.7 * *$ & $5.7 \pm 0.5^{* *}$ & $4.8 \pm 1.0^{* *}$ & $5.7 \pm 0.6^{* *}$ & $4.3 \pm 0.8^{* *}$ \\
\hline Forelimb anomaly & ND & ND & ND & ND & ND & ND \\
\hline Metacapals & $3.6 \pm 0.5$ & $3.8 \pm 0.4^{* *}$ & $3.8 \pm 0.4^{* *}$ & $3.3 \pm 0.5^{* *}$ & $3.9 \pm 0.3^{* *}$ & $3.4 \pm 0.5^{* *}$ \\
\hline Hindlimb anomaly & ND & ND & ND & ND & ND & ND \\
\hline
\end{tabular}

Values are given as mean \pm SD for No. of fetuses observed.

$\mathrm{ND}$, anomaly not detected.

a, No. of ossified bones.

***, significantly different from control at $\mathrm{p}<0.05$ and $\mathrm{p}<0.01$, respectively.

$\min \mathrm{A}$ (Table 6).

\section{DISCUSSION}

Micromass assay using LB and CNS cell has a lot of advantages in that these cells are originated from rat embryo, and undergo the differentiation process like embryo, and time of differentiation is very similar to embryo. These cells were suggested as a predictive short term assay for the teratogenicity of chemicals (Flint, 1993). The overall predictive accuracy of the system was approximately $89 \%$, and the false-negative rate was approximately $14.8 \%$ and no false positives were observed (Guntakatta, Matthews et al., 1984).

In this experiment for olaquindox, $\mathrm{IC}_{50}$ values of proliferation and differentiation for CNS cell were 22.74 and $28.32 \mu \mathrm{g} / \mathrm{ml}$, and 79.34 and $23.29 \mu \mathrm{g} / \mathrm{ml}$ for LB cell, respectively. Compounds with $\mathrm{IC}_{50}$ below $50 \sim 75 \mu \mathrm{g} / \mathrm{m} l$ on differentiation could be considered as potential of teratogenicity and $7 \sim 10 \mu \mathrm{g} / \mathrm{ml}$ or less with a high solubility may indicate high teratogenic risk (Flint, 1986). In vivo, development toxicant produce adverse effects on the fetus at exposure levels that do not induce severe toxicity in the mother such as substantial reduction in weight gain. Strong teratogen has selective effect on inhibition cell differentiation at concentration lower than causing cytotoxicity. Based on this assumption, olaquindox could be classified as a compound having a potential of teratogenicity especially in limb bud because differentiation of LB cell was completely inhibited at non-cytotoxic concentration but differentiation in CNS cells was observed at cytotoxic concentration of olaquindox. Regarding vitamin $\mathrm{A}, \mathrm{IC}_{50}$ values of proliferation and differentiation for CNS cell were 8.13 and $5.94 \mu \mathrm{g} /$ $\mathrm{m} l$, and 0.81 and $0.05 \mu \mathrm{g} / \mathrm{m} l$ for LB cell, respectively. Based on these data, vitamin A should be classified as a compound having a high teratogenic potential. Especially it would be a strong teratogen in LB cell in that the ratio of $\mathrm{IC}_{50}$ for cytotoxicity to $\mathrm{IC}_{50}$ for diffierentiation in $\mathrm{LB}$ cell about 16 but that in CNS was about 1.36. In the presence of active retinoids chondrogenesis is concentration-dependently inhibited (Kistler, 1987).

Retinoids is a well-known teratogen of limb-skeletal deletions, limb truncation and other skeletal malformations (Paulsen et al., 1988). Retinoid bind to the cellular retinoic acid bind protein and control the cell differentiation and embryonic morphorgenesis (Lehmann et al., 1992; Willhite et al., 1992; Soprano et al., 1993). In vivo experiment $5 \mathrm{mg} /$ $\mathrm{kg}$ of all-trans-retinoic acid was highly embryotoxic when administered subcutaneously, but not following oral administration. The most pronounced embryotoxic endpoints were embryolehtality and defect of skull, and the thorax, and the sternum (Tzimas et al., 1997). In this experiment, $56 \%$ of external anomaly such as craniorachschisis, exencephaly, dome shaped head, anophthalmia and brachygnathia and $87 \%$ of soft tissue anomaly such as cleft palate and anopththalmia were showed by high dose of vitamin A. High dose of vitamin A also produced $85 \%$ of skull anomaly and inhibited the ossifications of sternebrae and metacarpals. Conclusively our in vivo and in vitro data for vitamin A are very similar to previous results as a strong teratogen.

In NMRI mice, olaquindox $(180 \mathrm{mg} / \mathrm{kg})$ decreased the maternal body weight gain, without changing of the number of implantations, live fetuses, reabsorption and the incidence of malformations whereas rats given $180 \mathrm{mg} / \mathrm{kg}$ of olaquindox showed reduction in body weight gain, higher incidence of resorptions, lower numbers of live fetus and 
reduction of fetal weights. Five fetuses out of $20(25 \%)$ showed malformation at a dose level of $180 \mathrm{mg} / \mathrm{kg}$ (WHO, 1991). In this study, rats given $110 \mathrm{mg} / \mathrm{kg}$ showed lower mean body weight and increased rate of implantation and increased number of fetuses, but did not change in relative ovary weight, number of corpus lutea, and number of implantation. External anomaly scuh as bent tail was increased by $110 \mathrm{mg} / \mathrm{kg}$ of olaquindox. Dilatation of renal pelvis and lateral ventricle were shown at a dose level of $110 \mathrm{mg} / \mathrm{kg}$. In summary, olaquindox showed $6.8 \%$ of external anomaly and $1.9 \%$ of soft tissue anomaly without any skeletal anomaly at a dose level of $110 \mathrm{mg} / \mathrm{kg}$. Our present data suggest that a high dose of olaquindox could act as a teratogen in rats which might provoke external anomaly and delay of ossification of sternebrae and metacapals. But in pork industry it is added to feed at a dose of $25 \sim 100 \mathrm{mg} / \mathrm{kg}$ in feed so that we could expect little teratogenic effect of olaquindox in the practical application.

In conclusion, this present study supports that vitamin A could be classified as strong teratogen in micromass and in vivo, and olaquindox has a weak teratogenic potential in LB cell but not in CNS cell. The present result provides in vivo evidence that high dose of olaquindox could have weak embryotoxic potential in rats.

\section{ACKNOWLEDGEMENTS}

This project was supported by grants from National Veterinary Research and Quarantine Service, Republic of Korea.

\section{REFERENCES}

Aulthouse, A.L. and Hitt, D.C. (1994). The teratogenic effects of valproic acid in human chondrogenesis in vitro. Teratology, 49, 208-217.

Belhadjali, H., Marguery, M.C., Journe, F., Giordano-Labadie, F., Lefebvre, H. and Bazex, J. (2002). Allergic and photoallergic contact dermatitis to Olaquindox in a pig breeder with prolonged photosensitivity. Photodermatol. Photoimmunol. Photomed., 18, 52-53.

Beutin, L., Preller, E. and Kowalski, B. (1981). Mutagenicity of quindoxin, its metabolites, and two substituted quinoxaline-diN-oxides. Antimicrob. Agents. Chemother, 20, 336-343.

Bronsch, K., Schneider, D. and Rigal-Antonelli, F. (1976). [Olaquindox - a new growth promoter in animal nutrition. 1. Effectiveness in raising piglets]. Z. Tierphysiol. Tierernahr. Futtermittelkd., 36, 211-221.

Commission of the European Communities, Commission Regulation 2788/98, Off. J. Eur. Communities L347 (31-32), 1998, 1223.

Chen, Q., Tang, S., Jin, X., Zou, J., Chen, K., Zhang, T. and Xiao, X. (2009). Investigation of the genotoxicity of quinocetone, carbadox and olaquindox in vitro using Vero cells. Food Chem. Toxicol.,47, 328-334.

Ding, M.X., Wang, Y.L., Zhu, H.L. and Yuan, Z.H. (2006). Effects of cyadox and olaquindox on intestinal mucosal immunity and on fecal shedding of Escherichia coli in piglets. J. Anim. Sci., 84, 2367-2373.

Flint, O.P. (1986). An in vitro test for teratogens: its practical application. Food Chem. Toxicol., 24, 627-631.

Flint, O.P. (1993). In vitro tests for teratogens: desirable endpoints, test batteries and current status of the micromass teratogen test. Reprod. Toxicol., 7, 103-111.

Flint, O.P. and Orton, T.C. (1984). An in vitro assay for teratogens with cultures of rat embryo midbrain and limb bud cells. Toxicol. Appl. Pharmacol., 76, 383-395.

Guntakatta, M., Matthews, E.J. and Rundell, J.O. (1984). Development of a mouse embryo limb bud cell culture system for the estimation of chemical teratogenic potential. Teratog. Carcinog. Mutagen., 4, 349-364.

Hao, L., Chen, Q. and Xiao, X. (2006). Molecular mechanism of mutagenesis induced by olaquindox using a shuttle vector pSP189/mammalian cell system. Mutat. Res., 599, 21-25.

Kidney, J.K. and Faustman, E.M. (1995). Modulation of nitrosourea toxicity in rodent embryonic cells by O6-benzylguanine, a depletor of O6-methylguanine-DNA methyltransferase. Toxicol. Appl. Pharmacol., 133, 1-11.

Kistler, A. (1987). Limb bud cell cultures for estimating the teratogenic potential of compounds. Validation of the test system with retinoids. Arch. Toxicol., 60, 403-414.

Kistler, A. and Howard, W.B. (1990). Testing of retinoids for teratogenicity in vitro: use of micromass limb bud cell culture. Methods Enzymol., 190, 427-433.

Lehmann, J.M., Jong, L., Fanjul, A., Cameron, J.F., Lu, X.P., Haefner, P., Dawson, M.I. and Pfahl, M. (1992). Retinoids selective for retinoid X receptor response pathways. Science, 258, 1944-1946.

Liu, Z.Y., Huang, L.L., Chen, D.M., Dai, M.H., Tao, Y.F. and Yuan, Z.H. (2010). The metabolism and N-oxide reduction of olaquindox in liver preparations of rats, pigs and chicken. Toxicol Lett., 195, 51-59.

Paulsen, D.F., Langille, R.M., Dress, V. and Solursh, M. (1988). Selective stimulation of in vitro limb-bud chondrogenesis by retinoic acid. Differentiation, 39, 123-130.

Paulsen, D.F. and Solursh, M. (1988). Microtiter micromass cultures of limb-bud mesenchymal cells. In Vitro Cell Dev. Biol., 24, 138-147.

Schneider, D., Bronsch, K. and Richter, L. (1976). [Olaquindox--a new growth promoting feed additive. II. Effect on the performance in swine fattening]. Z. Tierphysiol. Tierernahr. Futtermittelkd., 36, 241-248.

Soprano, D.R., Tairis, N., Gyda, M., 3rd, Harnish, D.C., Jiang, H., Soprano, K.J. and Kochhar, D.M. (1993). Induction of RARbeta 2 gene expression in embryos and RAR-beta 2 transactivation by the synthetic retinoid Ro 13-6307 correlates with its high teratogenic potency. Toxicol. Appl. Pharmacol., 122, 159163.

Staples, R.E. and Schenell, V.L. (1964). Refinements in rapid clearing technique in the $\mathrm{KOH}$-alizarin red $\mathrm{S}$ method for fetal bone. Stain. Technol., 39, 61-63.

Tzimas, G., Thiel, R., Chahoud, I. and Nau, H. (1997). The area under the concentration-time curve of all-trans-retinoic acid is the most suitable pharmacokinetic correlate to the embryotoxicity of this retinoid in the rat. Toxicol. Appl. Pharmacol., 143, 436-444. 
WHO (1991). Joint FAO/WHO Expert Committee on Food Additives, WHO Food Additives Series 27, Olaquindox, Toxicological Evaluation of Certain Veterinary Drug Residues in Food (InChem; http://www.inchem.org).

Willhite, C.C., Jurek, A., Sharma, R.P. and Dawson, M.I. (1992). Structure-affinity relationships of retinoids with embryonic cellular retinoic acid-binding protein. Toxicol. Appl. Pharmacol.,
112, 144-153.

Wise, L.D., Clark, R.L., Rundell, J.O. and Robertson, R.T. (1990). Examination of a rodent limb bud micromass assay as a prescreen for developmental toxicity. Teratology, 41, 341-351.

Zanetti, N.C. and Solursh, M. (1984). Induction of chondrogenesis in limb mesenchymal cultures by disruption of the actin cytoskeleton. J. Cell. Biol., 99, 115-123. 